\title{
CULEX TORRENTIUM (MARTINI), A NEW SPECIES IN CROATIAN MOSQUITO FAUNA
}

\author{
Enrih Merdić*, Martina Kujavec, Marija Kovačević, Martina Žulu, \\ Nataša Graovac, Goran Vignjević \& Nataša Turić
}

Department of Biology, J.J. Strossmayer University of Osijek, Cara Hadriana 8a, 31000, Osijek, Croatia

Merdić, E., Kujavec, M., Kovačević, M., Žulj, M., Graovac, N., Vignjević, G. \& Turić, N.: Culex torrentium (Martini), a new species in Croatian mosquito fauna. Nat. Croat., Vol. 27, No. 2, 323-329, 2018, Zagreb.

In research into mosquitoes in the mountain regions of Croatia, a new species of mosquito for Croatian mosquito fauna has been identified. The Culex pipiens complex is represented with four sibling species. Culex torrentium belongs to this complex and morphologically differs from the other species only in the structure of male genitals. The presence of this species is determined based on the male genital structure and confirmed by mitochondrial cytochrome c oxidase molecular analysis. Specimens of these species have been found in all three mountain areas covered by this research: Slavonian mountains, Gorski Kotar area and central Velebit Mt. The lowest altitude where we found this species was 159 metres above sea level (m a.s.l.) in Pleternica, and the highest $906 \mathrm{~m}$ a.s.l. in Baške Oštarije. At all sites, the species $C x$. torrentium was sampled in community with other species, but most frequently together with sibling species of $C x$. pipiens (most probably the subspecies $C x$. p. pipiens).

Key words: Culex torrentium, Culex pipiens complex, Croatia

Merdić, E., Kujavec, M., Kovačević, M., Žulj, M., Graovac, N., Vignjević, G. \& Turić, N.: Culex torrentium (Martini), nova vrsta u hrvatskoj fauni komaraca. Nat. Croat., Vol. 27, No. 2, 323-329, 2018, Zagreb.

Faunističkim istraživanjem komaraca planinskih područja u Hrvatskoj zabilježena je nova vrsta komaraca za faunu Hrvatske. Culex pipiens kompleks predstavlja kompleks od četiri sestrinske vrste. Culex torrentium pripada tom kompleksu, a od drugih se vrsta razlikuje samo u građi genitalija mužjaka. Prisutnost ove vrste komaraca utvrđena je na osnovi razlika genitalija mužjaka, a potvrđena je molekularnom analizom mitohondrijalne citokrom c oksidaze. Jedinke ove vrste zabilježene su u svim istraživanim područjima u okviru ovog istraživanja: planine u Slavoniji, Gorskom Kotaru i srednjem Velebitu. Najniža nadmorska visina na kojoj je zabilježeno prisustvo ove vrste bila je $159 \mathrm{~m}$ u Pleternici, a najviša na $906 \mathrm{~m}$ u Baškim Oštarijama. Na svim postajama Cx. torrentium je zabilježen u zajednici s drugim komarcima, ali najčešće sa sestrinskom vrstom $C x$. pipiens (najvjerojatnije podvrstom $C x . p$. pipiens).

Ključne riječi: Culex torrentium, Culex pipiens kompleks, Hrvatska

\section{INTRODUCTION}

Various authors have described the Culex pipiens complex as several species, subspecies, forms, races, physiological variants, or biotypes. This complex includes the names Cx. pipiens pipiens Linnaeus, $C x$. p. pipiens biotype molestus Forskal, Cx. p. quinquefascia-

\footnotetext{
*corresponding author: enrih@biologija.unios.hr
} 
tus Say, Cx. p. pallens Coquillett, Cx. restuans Theobald, and Cx. torrentium Martini in the Holarctic as well as two Australian members, $C x$. australicus Dobrotworsky and Drummond and Cx. globocoxitus Dobrotworsky (BECKer et al., 2010).

$C x$. torrentium is considered to be a sibling species of the $C x$. pipiens complex. Females and larvae of $C x$. pipiens and $C x$. torrentium are morphologically nearly identical and although for a long time, considered to occupy different habitats and geographical areas, they are well defined and separated species genetically. Based on larval collections and molecular species identification, recent studies have shown that the species often occur together, and that $C x$. torrentium dominates in northern Europe and is as common as Cx. pipiens in Central Europe (Hesson et al., 2015). Consequently, it is rare in Southern Europe. They share comparable ecological characteristics regarding the habitat of the adults as well as breeding sites and an almost identical morphology (SHERPNER, 1960). The only reliable distinguishable morphological characteristic is the structure of the male hypopygium. Cx. torrentium has the dorsal arm of the aedeagus twisted and pointed apically and the ventral arm of paraproct well developed, strongly sclerotized. In contrast to Cx. pipiens, $C x$. torrentium is adapted to lower water temperatures and dominates in cold regions or at higher altitudes (SCHAFFNER et al., 2001). Differences between sibling species $C x$. torrentium and $C x$. pipiens can be determined using mitochondrial cytochrome oxidase c subunit I. The most efficient approach in the differentiation of these two species is using both the morphological and the molecular approach. $C x$. torrentium is present in many countries of Central Europe (WeitzeL et al., 2011), but its presence in Croatia was not confirmed until now.

The aim of this research was to investigate the presence of sibling species of $C x$. pipiens and $C x$. torrentium in Croatia. If it was present, our next aim was to determine how its range depends on altitude and climate conditions.

\section{Study area}

Sample collection was carried out in three areas (Fig. 1) of higher altitude for which there is little or no information on mosquito species. We chose the areas of Slavonian mountains, Gorski Kotar and the Central Velebit. All the areas are characterized by higher altitudes, more forest vegetation and higher rainfall than in the rest of Croatia, which contributes to the emergence of forest streams, lakes and ponds. Because of different soil permeability and dry weather during research we also paid attention to artificial water collections (e.g. tires, bath tubs, barrels).

The first area is located on the Slavonian mountains which surround the Požega valley. The selected transect included Mt Papuk and Požeška Gora with a maximum altitude of $515 \mathrm{~m}$ (forest near Novo Zvečevo) and minimum altitude of $177 \mathrm{~m}$ (forest near Požeška Koprivnica). The second area is located in Gorski Kotar from the foot of Samarske stijene (maximum altitude of $1011 \mathrm{~m}$ ) to Brod na Kupi (minimum altitude of 234) in the north and Bribir in the south. Gorski Kotar is a plateau with an average height of 700-900 $\mathrm{m}$ from which the mountains range up to $1500 \mathrm{~m}$. The climate is extremely montane. The third area is located in Central Velebit from Gospić in the east, Baške Oštarije and Brušane in the south and Krasno (Northern Velebit) in the north. The highest altitude was on the rocks behind Dabarski kukovi (1003 m) and in Štirovača (1012 m). The lowest altitude was in the village Kuterevo (529 m). Mt. Velebit is a natural border between continental and Mediterranean Croatia. 


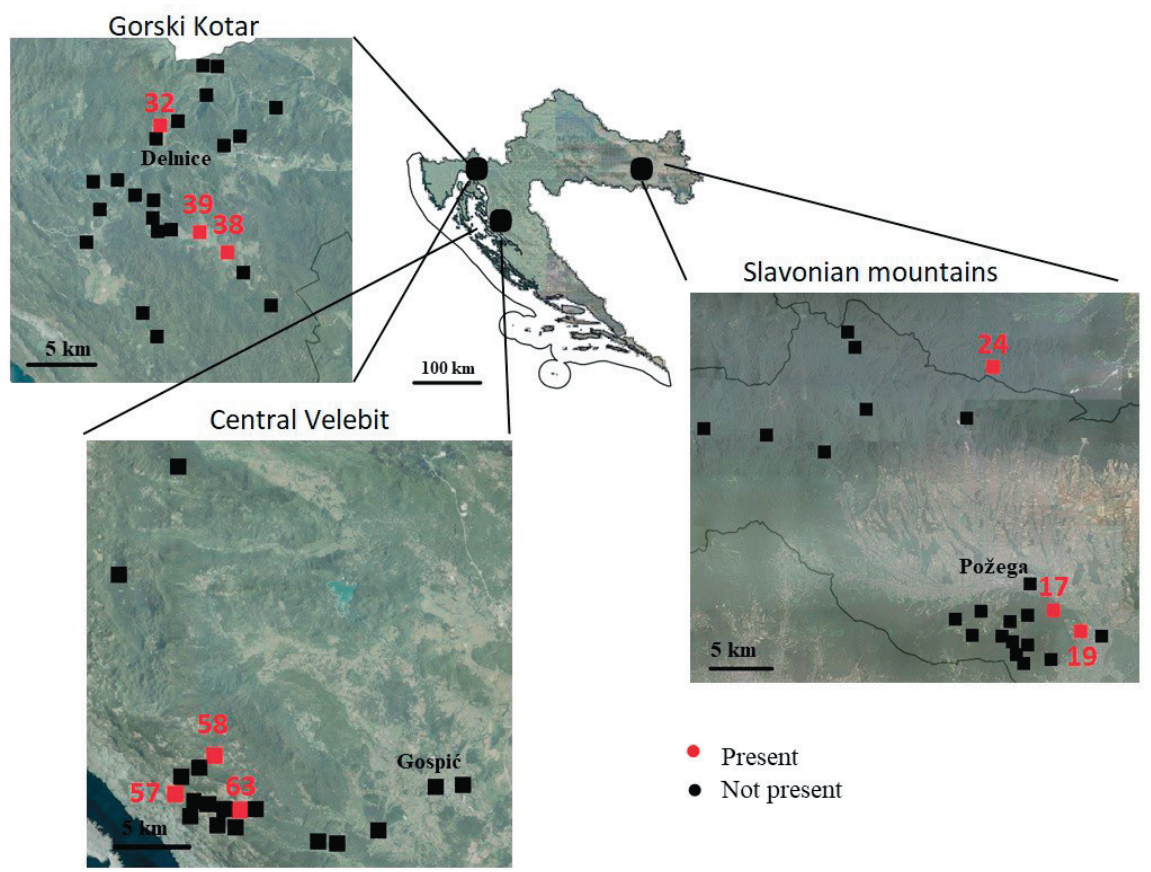

Fig. 1. Study area and locations where $C x$. torrentium was recorded.

\section{MATERIALS AND METHODS}

The study was conducted during July and August 2017. Adult stages, as well as larvae were sampled at 68 localities, once per locality: 24 on the Slavonian mountains, 24 in Gorski Kotar and 20 in Central Velebit. Longitude and latitude of each locality were recorded using a geographical positioning system (GPS), and were later displayed using GoogleEarth.

Adult mosquitoes were caught using CDC traps in 30 of the 68 localities. Traps were baited using dry ice as attractant for mimicking $\mathrm{CO}_{2}$ emission from live hosts. Adult mosquitoes were also collected using BG Sentinel traps with their usual attractant coupled with dry ice. BG Sentinel traps were placed aat 6 localities. All the traps were set in an appropriate habitat and were operated for at least 12 hours, including dusk and dawn. Sampled mosquitoes were stored in the entomological collection of the Department of Biology, Josip Juraj Strossmayer University of Osijek. Later, specimens were identified using the following keys: Becker et al. (2010), and Gutsevich et al. (1974).

Larvae were caught individually using a plastic dropper or using a net $25 \mathrm{~cm}$ in diameter with a dipper to collect the water containing the larvae. Larvae were collected from all natural and artificial habitats: ponds and channels and barrels and tyres, for example, respectively. Half of the collected specimens were brought to the laboratory and left to emerge so that we could obtain adult mosquitoes. After imagoes emerged they were either killed using potassium cyanide (KCN) and mounted on entomological pins following the identification using identification keys, or stored in $100 \%$ ethanol for later molecular identification to identify $C x$. torrentium. The specimens 
in the other were killed in the field by being placed in $100 \%$ ethanol for the making of permanent preparations. In some emerged male mosquitoes, (Culex pipiens complex) the genitalia were removed, exposed in hot $\mathrm{KOH}$ for 10 minutes, placed on a microscope slide in a drop of Canada balsam and covered with a coverslip. Afterwards, they were covered with a cover plate and identified using the identification keys BECKER et al. (2010), and Gutsevich et al. (1974).

DNA was extracted from whole mosquito samples using DNeasy Blood \& Tissue Kit (Qiagen, Hilden, Germany) according to the manufacturer's protocol. DNA fragment for mitochondrial cytochrome c oxidase subunit I (COI) was amplified using standard PCR protocol and cycling conditions $\left(3 \mathrm{~min}\right.$ at $94^{\circ} \mathrm{C}, 39 \times\left(20 \mathrm{~s}\right.$ at $94^{\circ} \mathrm{C}, 40 \mathrm{~s}$ at $52^{\circ} \mathrm{C}, 30 \mathrm{~s}$ at $\left.72^{\circ} \mathrm{C}\right), 5 \mathrm{~min}$ at $72^{\circ} \mathrm{C}$ ). PCR products were visualized using gel electrophoresis. PCR products were later sent for sequencing (Macrogen, Amsterdam, Netherland).

\section{RESULTS}

Specimens of the $C x$. pipiens complex were sampled as adults and larvae. As adult mosquitoes cannot be determined to species level these samples were not taken into consideration in this paper (adult mosquitoes were caught in CDC as well as BG Sentinel traps). In total we found $C x$. pipiens complex larvae in 26 sites. After emergence and analysis of male genital morphology, we noted the presence of $C x$. torrentium at 9 sites. A total of 38 mosquitoes from these 9 sites were subjected to molecular analysis.

Presence of the $C x$. torrentium species was determined using morphological analysis of male hypopygia and confirmed using molecular analyses. In three areas covered by this study we investigated 68 localities and in 9 we noted the presence of $C x$. torrentium (Fig. 1). The presence was noted at 159, 183, $347 \mathrm{~m}$ a.s.l., in the Slavonian mountains, 712, 776 and 777 m a.s.l. in Gorski Kotar and 619, 712 and 906 m a.s.l. on Mt Velebit (Fig. 2).

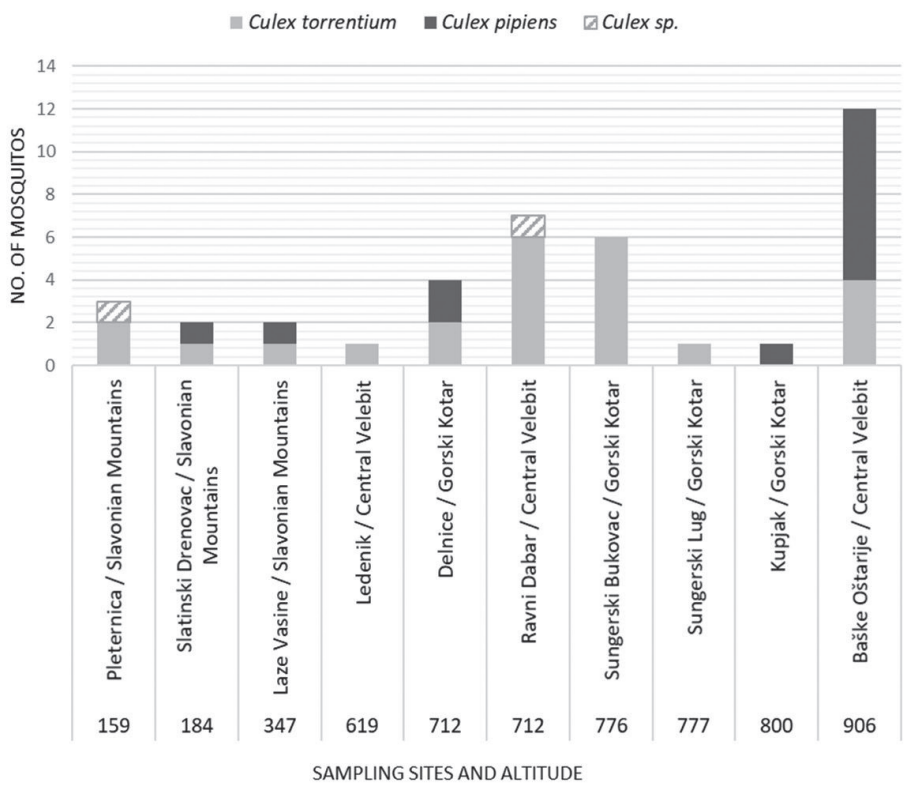

Fig. 2. Species composition of males from Cx. pipiens complex in investigated sites in the mountains of Croatia. 
Analyzing the males from the $C x$. pipiens complex we identified 38 individuals, of which 25 were identified as $C x$. torrentium, 13 as $C x$. pipiens and two remained undefined to species level and we noted them as Culex sp. Two sibling species, $C x$. pipiens and $C x$. torrentium occurred together at 4 sites of which two were at lower altitudes $(<350$ $\mathrm{m}$ a.s.1.) and two at higher altitudes ( $>600 \mathrm{~m}$ a.s.l.). C $x$. torrentium was found alone in three sampling sites at higher altitudes (>600 m a.s.l.) (Fig. 2).

In almost all sites we noted the presence of $C x$. torrentium with other mosquito species on the same sampling sites (Tab. 1). In the first area (Slavonian mountains), $C x$. torrentium occurred together with $C x$. pipiens, Anopheles maculipennis and Aedes japonicus, and in the second (Gorski Kotar) with Cx. pipiens, Culex sp., Ae. japonicus, Culex hortensis, Culiseta longiareolata and Ochlerotatus sp. In the third area (Central Velebit) Cx. torrentuim occurred with Cx. pipiens, Culex sp., Ae. japonicus, Cx. hortensis, An. maculipennis, Cs. longiareolata, Culiseta annulata and Culiseta sp.; in the Ledenik site we sampled Cx. torrentium only.

Tab. 1. Presence of Culex torrentium with other mosquito species in the larval stage on the same sampling sites.

\begin{tabular}{|c|c|c|c|c|}
\hline $\begin{array}{l}\text { Mark on } \\
\text { the map }\end{array}$ & Location & Altitude & Habitat & Species \\
\hline \multirow{5}{*}{19} & \multirow{5}{*}{ Pleternica / Slavonian mountains } & \multirow{5}{*}{159} & \multirow{5}{*}{ Canal } & Culex pipiens \\
\hline & & & & Culex territans \\
\hline & & & & Culex torrentium \\
\hline & & & & Culex sp. \\
\hline & & & & Anopheles maculipennis \\
\hline \multirow{4}{*}{24} & \multirow{4}{*}{ Slatinski Drenovac / Slavonian mountains } & \multirow{4}{*}{184} & \multirow{4}{*}{ Barrel } & Culex pipiens \\
\hline & & & & Aedes japonicus \\
\hline & & & & Culex torrentium \\
\hline & & & & Anopheles maculipennis \\
\hline \multirow{3}{*}{17} & \multirow{3}{*}{ Laze Vasine / Slavonian mountains } & \multirow{3}{*}{347} & \multirow{3}{*}{ Well } & Culex pipiens \\
\hline & & & & Culex torrentium \\
\hline & & & & Aedes japonicus \\
\hline 58 & Ledenik / Central Velebit Mt. & 619 & Cemetery & Culex torrentium \\
\hline \multirow{5}{*}{32} & \multirow{5}{*}{ Delnice / Gorski Kotar } & \multirow{5}{*}{712} & \multirow{5}{*}{ Yard } & Culex pipiens \\
\hline & & & & Culex torrentium \\
\hline & & & & Culex hortensis \\
\hline & & & & Culex sp. \\
\hline & & & & Aedes japonicus \\
\hline \multirow{6}{*}{57} & \multirow{6}{*}{ Ravni Dabar / Central Velebit Mt. } & \multirow{6}{*}{712} & \multirow{6}{*}{ Barrel } & Culex pipiens \\
\hline & & & & Culex hortensis \\
\hline & & & & Culex sp. \\
\hline & & & & Culex torrentium \\
\hline & & & & Culiseta longiareolata \\
\hline & & & & Culiseta sp. \\
\hline \multirow{6}{*}{39} & \multirow{6}{*}{ Sungerski Bukovac / Gorski Kotar } & \multirow{6}{*}{776} & \multirow{6}{*}{ Barrel } & Culex pipiens \\
\hline & & & & Culex torrentium \\
\hline & & & & Culex sp. \\
\hline & & & & Aedes japonicus \\
\hline & & & & Culiseta longiareolata \\
\hline & & & & Ochlerotatus sp. \\
\hline
\end{tabular}




\begin{tabular}{|c|l|c|c|l|}
\hline $\begin{array}{c}\text { Mark on } \\
\text { the map }\end{array}$ & Location & Altitude & Habitat & Species \\
\hline 38 & Sungerski Lug / Gorski Kotar & 777 & Canal & Culex pipiens \\
\hline \multirow{2}{*}{63} & Baške Oštarije / Central Velebit Mt. & & & Culex torrentium \\
\hline & & \multirow{2}{*}{906} & \multirow{2}{*}{ Trough } & Culex torrentium \\
\cline { 5 - 5 } & & & & Culiseta longiareolata \\
\hline & & & Culiseta annulata \\
\hline & & & Aedes japonicus \\
\hline
\end{tabular}

\section{DISCUSSION}

The species that we most often found to be dominant in this research belongs in the $C x$. pipiens complex. Since it belongs among cosmopolitan species and was found up to $2500 \mathrm{~m}$ a.s.l. (GuTsEvich et al., 1974), this relatively low area is not a problem for their life. This species can be found everywhere, because it can breed in almost any kind of water habitat with any kind of food (Merdić, 1993). During our research, mosquitoes had large quantities of food available, so it is not unusual that we should have found them in large numbers.

These two species occur together in large areas of Europe; $C x$. torrentium dominates in Northern Europe and $C x$. pipiens dominates south of the Alps. The transition in dominance occurs in Central Europe, where both species are roughly equally common (Hensson et al., 2014). There is a strong correlation between the length of the growing season at different sites and occurrences of the two species. As the growing season increases, the proportion and detection of $C x$. torrentium decrease, whereas those of $C x$. pipiens increase. In Croatia, the lower altitudes are very convenient for $C x$. pipiens, but higher altitudes are similar to Northern Europe and better for the species which dominates in Northern Europe. It would be interesting for future research to find these mosquitoes at altitudes more than $1500 \mathrm{~m}$ a.s.l..

The presence of $C x$. torrentium was confirmed using morphological and molecular analysis. $C x$. torrentium populations were found in all areas covered by this research (Slavonian mountains, Gorski Kotar and Central Velebit). Distribution of Cx. torrentium depends on climate factors and the site altitude. In the area of the Slavonian mountains and Gorski Kotar, the distribution of $C x$. torrentium probably depends more on the continental climate than on the higher altitudes. For example, in the area of the Slavonian mountains we found $C x$. torrentium in lower altitudes on northern slopes and in fresh spring water, whereas at higher altitudes in warmer standing water we found both species. In the Gorski Kotar area we mostly found $C x$. torrentium, probably due to the impact of the colder climate. In the area of central Velebit, where the impact of Mediterranean climate is stronger, both species are present at higher altitudes, but we found the dominance of $C x$. torentium in north Velebit, which might depend on higher altitude only.

Different species of the $C x$. pipiens complex are vectors for a number of arboviruses such as Japanese encephalitis, Sindbis and Usutu virus, but the West Nile Virus (WNV) is the most important for Europe (BECKER et al., 2010). The occurrence of WNV human infections in Croatia was recorded several years ago. The first outbreak of WNV neuroinvasive disease with seven human cases occurred in 2012 in three north-eastern 
Croatian counties (Merdić et al., 2012), after that, an outbreak occurred in Central and Northern Croatia (Vilibić ČAvleK at al., 2014). Human cases of WNV fever and WNV neuroinvasive disease were recorded in many Central European countries. During the 2017 transmission season, 288 human cases were reported in the EU and neighbouring countries. In addition, EU Member States reported 127 equine cases (ECDC, 2018). WNV is maintained in nature within an enzootic cycle involving ornithophilic mosquitoes and birds, but it can infect humans and equines (incidental or dead-end hosts). The $C x$. pipiens complex members $C x$. pipiens biotypes pipiens and molestus, as well as Cx. torrentium, are abundant in Central Europe (Hensson et al., 2014). Both species preferentially take blood meals from birds, rendering them potential enzootic vectors for WNV in Central Europe. Slightly higher infection and dissemination rates even at a low average ambient temperature of $18^{\circ} \mathrm{C}$ have been proven in Cx. torrentium (LeGGEWIE et al., 2016).

The first record of $C x$. torrentium in Croatia represents a new member of Croatian fauna which has not been registered so far because of lack of molecular identification. Further studies are needed to determine the presence of this mosquito species in the Croatian lowlands.

Received June 12, 2018

\section{REFERENCES}

Becker, N., Petrić, D., Zgomba,, M., Boase, C., Madoon, M., Dahl, C. \& Kaiser, A., 2010: Mosquitoes and their control. Springer, Berlin. p 124-234.

ECDC, 2018 - https://www.ecdc.europa.eu/en/home (accessed on May 24, 2018)

Gutsevich, A.V., MonchadskiI, A.S. \& Stackelberg, A.A., 1974: Mosquitoes. Family Culicidae. Fauna of the USSR. Diptera, 3, p. 1-408. (Jerusalem, English translation).

Hesson, J. C., Rettich, F., Merdić, E., Vignjević, G., Östman, Ö., Schäfer, M., Schaffner, F., Foussadier, R., Besnard, G., Мedlock, J., Scholte, E. J. \& Lundström, J. O., 2014: The arbovirus vector Culex torrentium is more prevalent than Culex pipiens in northern and central Europe. Medical and Veterinary Entomology, 28, 179-186. doi: 10.1111/mve.12024

Hesson, J. C., Ignell, R., Hill, S. R., Östman, Ö., \& Lundström, J. O., 2015: Trapping biases of Culex torrentium and Culex pipiens revealed by comparison of captures in CDC traps, ovitraps, and gravid traps. Journal of Vector Ecology, 40 (1), 158-163.

Leggewie, M., Badusche, M., Rudolf, M., Jansen, S., Börstler, J., Krumkamp, R. \& Becker, S. C., 2016: Culex pipiens and Culex torrentium populations from Central Europe are susceptible to West Nile virus infection. One Health, 2, 88-94.

Merdić, E., 1993: Mosquitoes (Diptera, Culicidae) of the special zoological reserve Kopački rit (NE Croatia). Natura Croatica, 2 (1), 47.

Merdić, E., Perić, Lj., Pandak, N., Kurolt, I. C., Turić, N., Vignjević, G., Štolfa, I., Milas, J., Sudarić Bogojević, M. \& Markotić, A., 2013: West Nile Virus Outbreak in Humans in Croatia, 2012. Collegium antropologicum, 37 (3), 943-947.

Schaffner, F., Angel, G., Geoffroy, B., Hervy, J. P., Rhaiem, A. \& Brunhes, J., 2001: The mosquitoes of Europe. Paris: IRD editions. CD-ROM.

SCherpNer, C., 1960: Zur Ökologie und Biologie der Stechmücken des Gebietes Frankfurt am Main (Diptera, Culicidae). Mitt Zool Mus Berlin 36, 49-9.

Vilibić-Čavlek, T., Kaić, B., Barbić, Lj., Pem-Novosed, I., Slavić-Vrzić, V., Lesnikar, V., Kurečić-Filipović, S., Babić-Erceg, A., Listeš, E., Stevanović, V., Gjenero-Margan, I. \& Savini, G.., 2014: First evidence of simultaneous occurrence of West Nile virus and Usutu virus neuroinvasive disease in humans in Croatia during the 2013 outbreak. Infection, 42, 689-695.

Weitzel, T., Braun, K., Collado, A., Jöst, A. \& Becker, N., 2011: Distribution and frequency of Culex pipiens and Culex torrentium (Culicidae) in Europe and diagnostic allozyme markers. European Mosquito Bulletin, 29, 22-37. 
